Article

\title{
Respirometric Index and Biogas Potential of Different Foods and Agricultural Discarded Biomass
}

\author{
Simona Ciuta ${ }^{1}$, Stefano Antognoni ${ }^{2}$, Elena Cristina Rada ${ }^{2,3, *}$, Marco Ragazzi $^{2}$, Adrian Badea ${ }^{1,4}$ \\ and Lucian Ionel Cioca ${ }^{3,4}$ \\ 1 Department of Energy Production and Use, Politehnica Univeristy of Bucharest, Splaiul Independentei, 313, \\ Bucharest 060042, Romania; mciuta@ccny.cuny.edu (S.C.); badea46@yahoo.fr (A.B.) \\ 2 Department of Civil, Environmental and Mechanical Engineering, University of Trento, via Mesiano, 77, \\ Trento 38123, Italy; stefano.antognoni@unitn.it (S.A.); marco.ragazzi@unitn.it (M.R.) \\ 3 Department of Industrial Engineering and Management, Faculty of Engineering, \\ Lucian Blaga University of Sibiu, Bulevardul Victoriei, 10, Sibiu 550024, Romania; lucian.cioca@ulbsibiu.ro \\ 4 Academy of Romanian Scientists, Splaiul Independentei, 54, Sector 5, Bucharest 010071, Romania \\ * Correspondence: elena.rada@unitn.it; Tel.: +39-0461-282613
}

Academic Editors: Vincenzo Torretta and Marc A. Rosen

Received: 8 October 2016; Accepted: 6 December 2016; Published: 14 December 2016

\begin{abstract}
The biological stability of biomass is an important parameter for treatment plant design, process control or compost use. Measuring the biological reactivity of waste with the help of indicators such as respirometric indexes (RI) becomes an important tool to prevent the significant environmental impact of biodegradable wastes in accordance with European legislation. The aim of this paper is to show the importance of the RI technique as a tool to establish further uses of biomass such as fertilizer or biogas. The respirometric process length for different types of biomass (grape marc, apple pomace and olive pomace) was quantified. Higher moisture content seemed to favor the biological activity during the respirometric experiments and shorten the length of the process. The duration of olive pomace respirometry did not exceed 3 days, while the respirometric activity of apple scraps the lasted approximately 2 days. The highest RI values were encountered for the apple pomace, $4888 \mathrm{mgO} \cdot \mathrm{kgVS}^{-1} \cdot \mathrm{h}^{-1}$. The majority of the discarded biomasses are categorized in the third class of stability materials in the course of degradation. This technique is important to detect the biodegradability of substrates, as well as to gain insight into the quantity and generation rate of biogas produced, information that is important from an engineering management perspective.
\end{abstract}

Keywords: respirometric index; biomass; anaerobic digestion; biogas; grape marc

\section{Introduction}

In the European Union's newly joined countries, biodegradable waste represents a significant portion of the total municipal solid waste (MSW). This could be a problem in terms of compliance with the European Council Directive on landfilling of waste [1] (Directive 1999/31/EEC) which requires member states to reduce the amount of biodegradable municipal solid waste (BMSW) in landfills, over a 15-year period, to 35\% of the amount produced in 1995. This has led to strategies for segregation of the organic and non-organic waste fractions and BMSW treatment such as volume reduction, reutilization or energy recovery.

Furthermore, higher demand of agricultural products has led to the augmentation of wastes from food and agricultural industries. These agricultural wastes are not yet valorized in developing countries and represent an additional expense to be discarded by producers $[2,3]$.

Although landfills are the most commonly used method for waste disposal [4], other biological treatment strategies can be applied to biodegradable and high moisture content wastes, such as 
composting, bio-drying or anaerobic digestion [5]. Compost produced using organic wastes is used for amendment in agricultural soils due to high and stabilized organic matter content [6,7], whereas bio-drying process allows biodegradable waste to be re-used as refuse-derived products [8].

An important parameter in efficient design of treatment plants, process control or compost use is the biological stability of biomass [9]. This indicates the degree to which the biodegradable organic matter decomposes. Therefore, measurement of biological reactivity has become important as it allows the classification of treated and untreated MSW and derived products, prior to their disposal in landfills, on the basis of their potential impact [10].

One of the most commonly used methods for biological stability measurement is the respirometric index (RI), which has seen much interest in the specialized literature. The respirometric technique is an indirect, simple and efficient method of determining the degree to which the biomass organic fraction decomposes, in relation to two important biochemical phenomena: the biological activity and the substrate consumption [11].

The respirometric method is an oxidative exothermic process, operated by aerobic microorganisms which consume oxygen with simultaneous production of water and carbon dioxide [12]. As reported by [11], the respirometric index represents the quantity of oxygen consumed by microorganisms per unit of present volatile solids and over time.

The respirometric tests, based on the oxygen consumption measurement, can be categorized as static or dynamic methods [12,13], with measurements performed in the absence (static) or presence (dynamic) of continuous aeration of the biomass. The static methods performed at constant volume or at constant pressure have the disadvantage of limiting diffusion and dispersion of oxygen in the biomass and therefore slowing down the decomposition of the organic fraction [11]. In dynamic systems, the continuous aeration of the substrate guarantees an optimum oxygen concentration for the biological activity at each moment of time [12,14].

Worldwide, several methods for respiration index determination are used. In Italy and USA, Static Respiration Index is used, in the first case accompanied by the Dynamic Respiration Index-Di.Pro.Ve methods [14]; in the UK-the specific oxygen uptake rate (SOUR) is most commonly used; in Germany and Austria the AT4 index for respiration activity in 4 days is mostly applied $[12,14]$. According to the literature $[15,16]$ the dynamic method presents several important advantages, such as: presence of continuous airflow during measurement which does not limit the oxygen transfer through the biomass layer; the possibility of working on large amounts of samples and on full-scale particle size; and the possibility of measurement of the airflow rate required to degrade waste under optimal conditions.

The maturity of compost is evaluated on the basis of growth potential and phytotoxicity of the vegetal species, while stability is a concept related simply to the microbial activity, in relation to the presence of degradable substrate. For the Italian dynamic respiration index (DRI) method developed by [10], the biological stability values reported for fresh and mature compost are 1000 and $500 \mathrm{mgO}_{2} \cdot \mathrm{kg}_{\mathrm{VS}}{ }^{-1} \cdot \mathrm{h}^{-1}$, respectively. According to the European legislation framework, the achievement of either a Respiration Activity after four days (AT4) below $10 \mathrm{mgO}_{2} \cdot \mathrm{g}_{\mathrm{DM}}{ }^{-1}$ or a Dynamic Respiration Index below $1000 \mathrm{mgO}_{2} \cdot \mathrm{kg}_{\mathrm{VS}}{ }^{-1} \cdot \mathrm{h}^{-1}$ shall deem that the material is not biodegradable waste [12].

Measuring the biological reactivity of waste with the help of indicators such as respirometric indexes is an important tool to prevent the significant environmental impact of biodegradable wastes, in accordance with the European legislation. The aim of this paper is to establish the biodegradability degree of different substrates and investigate the use of the respirometric index method as a tool for determining further uses of organic wastes. In addition, the biodegradability of the analyzed substrates was correlated with their biogas release potential through anaerobic digestion.

Anaerobic digestion plant operators often have to choose which biomasses to use, depending on the substrate digestibility and economical convenience. In this context, rapid methods for assessing biogas generation potential are needed. Anaerobic biogas potential (ABP) tests are reliable, but their 
response time (21 days for the partial biogas production and 100 days for the total biogas production) is very long $[9,17,18]$. As the availability of organic matrixes on the market varies day by day, rapid evaluations of the $\mathrm{ABP}$ are needed. Studies from the literature assumed an indirect and faster method to evaluate the ABP through a respirometric approach $[19,20]$. The result can be considered satisfactory as a compromise between precision and speed of the assessment.

One other significant use of biogas potential estimation is the assessment of methane as a greenhouse gas and environmental impact of organic waste sent to landfills. In accordance with the European legislation, MSW to be landfilled can be characterized through respirometric tests correlated with biogas emissions monitoring to determine its biological stability.

The present paper also proposes to determine the biogas potential production (ABP) from biodegradable waste using the Dynamic Respirometric Index values $[19,20]$ obtained during the laboratory tests carried out with the AIR-nl method in the engineering laboratories at the University of Trento.

\section{Materials and Methods}

\subsection{Selected Biomass}

Six different types of biomass were analyzed in this work, generated by agricultural activities or food industries: four types of grape marc (GM), apple pomace (AP) from apple processing industry and olive pomace (OP). Special attention was given to the wine-making industry wastes, due to the great availability of grapes worldwide and to the large quantities of wastes generated [21,22].

The grape marc used was collected from different wine producers and distilleries in Northern Italy, Trentino alto Adige. One of the products analyzed derived from white (W) grapes after the pressing and wine making process; the second product is represented by grape marc from red (R) grapes generated through the same wine making process. The other two types of grape marc are represented by the remains from the distillation process of white and red grapes. The waste derived from the wine making process was referred to as fresh grape marc (FGM), while the waste obtained from the distillation process was called exhausted grape marc (EGM) [23].

The apple scraps represent a waste product in the apple processing industry for food, fruit juices or ciders production. AP consists of peels, residues from pulp, seeds and petioles. Because of high moisture content (more than 50\%), apple scraps are best suited for energy recovery through biological methods, such as aerobic and anaerobic processes.

Olive pomace is a by-product of olive oil extraction process consisting of skins, pulp residues and fragments of pits. Among the main uses of $\mathrm{OP}$ are extractions for cosmetics, food products or agricultural land fertilizer. Currently, treatment of olive residues is performed by separating water, hulls and the pulp from the pits [24].

Primary and proximate analysis was performed on all six biomasses. Samples from each of the materials were collected and shredded prior to characterization. The samples were kept in a heated oven at $105^{\circ} \mathrm{C}$ for $24 \mathrm{~h}$ to determine the biomass moisture content and for $40 \mathrm{~min}$ at $800^{\circ} \mathrm{C}$ to measure the volatile solid content. Using a Calorimeter C200 the high heating value of the dried samples was determined. The elemental analysis of the products was performed with an Elemental Analyzer EA3000 and the chlorine and mercury content was established for further classifications as derived fuels. The outcome of these experiments is presented in the Results section of this paper.

\subsection{Experimental Setup}

The respirometric reactor used was built during a Ph.D. thesis at the University of Trento, Italy [9]. The project was based on a typical sealed respirometer for sludge treatment, in which a probe monitors the progressive decrease of oxygen, from a maximum value near saturation to a minimum set value, chosen for preventing limiting conditions. When it reaches its inferior value, a small compressor automatically starts to re-circulate the air within the reactor. In this way, the oxygen variation curve can be translated into a detailed respirometer diagram which is not limited in time. 
The respirometer (Figure 1) is made out of a steel reactor hermetically closed (volume $18 \mathrm{~L}$ ), in which a plastic recipient with perforated bottom is placed. Temperature is measured continuously by a thermocouple $\left(0-50^{\circ} \mathrm{C}\right)$. The reactor is insulated, connected to a thermostat (maintained at $30^{\circ} \mathrm{C}$ ) and completely enclosed in a thermal container in which all the components of the air re-circulating circuit are housed.

The aeration and analysis system is composed of a double pneumatic circuit: the first circuit for the continuous measurement of oxygen concentration which transports a lower flow rate of air, and the second circuit which allows the aeration of the sample transporting a higher air flow rate $\left(18 \mathrm{~L} \cdot \mathrm{min}^{-1}\right)$. In the first circuit a humidifier was placed to avoid the excessive decrease of sample moisture, while in the second circuit a container with silica salts is placed to dehumidify the air passing through the sample. The system is connected via a control unit for data acquisition to a computer that records temperature and oxygen concentration data within the reactor at regular intervals of $1 \mathrm{~min}$.

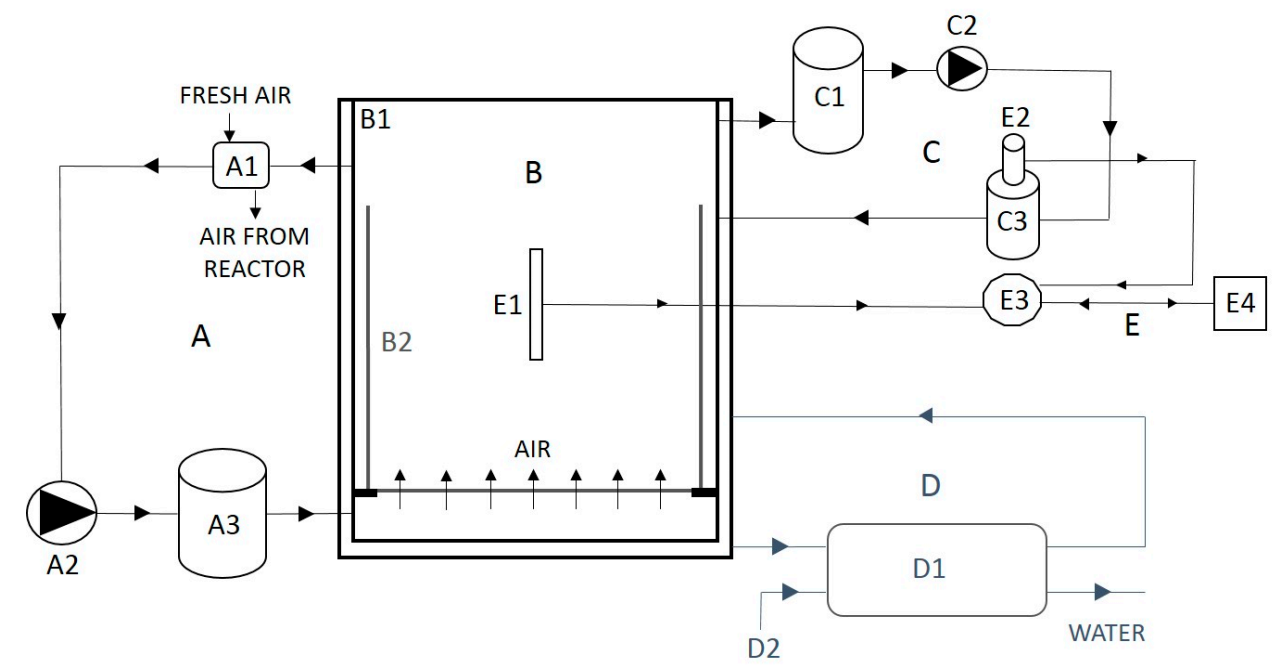

Figure 1. Respirometer AIR-nl 2002 schematic. A: Main pneumatic circuit; A1: Air recirculation electro valve; A2: Pump; A3: Humidifier. B: Reactor; B1: Sealed chamber for temperature control; B2: container with perforated bottom. C: Secondary pneumatic circuit for $\mathrm{O}_{2}$ measurement; $\mathrm{C} 1$ : Dehumidifier; C2: Micro pump; C3: Measuring cell. D: Circuit of thermoregulation; D1: Heater; D2: Cooling device. E: Transmission/Data acquisition; E1: Temperature probe; E2: Oxygen probe; E3: Acquisition/control unit; E4: Computer [20].

During the respirometric experiments, the temperature and oxygen volumetric percentage of the system are continuously monitored. The aim of the respirometric test is to measure the respirometric activity referred to as respirometric index (RI), which quantifies the $\mathrm{O}_{2}$ consumption rate of the decomposing bacteria. The RI refers to the volatile solids (VS) unit present initially in the sample.

Data measured with the $\mathrm{O}_{2}$ probe represents a volumetric percentage. In order to convert the percentage of $\mathrm{O}_{2}$ into $\mathrm{mgO}_{2}$, it was assumed that the air behaves like an ideal gas. Applying the Gay-Lussac law for ideal gases, Equation (1) is obtained:

$$
\mathrm{n}_{\mathrm{O}_{2}}=\frac{\mathrm{p} \times \mathrm{V}_{\mathrm{O}_{2}}}{\mathrm{R} \times \mathrm{T}}=\frac{\mathrm{p} \times \mathrm{V} \times \% \mathrm{O}_{2}}{\mathrm{R} \times \mathrm{T}}[\text { mole }]
$$

The process takes place at constant atmospheric pressure. Knowing the number of $\mathrm{O}_{2}$ moles and $\mathrm{O}_{2}$ molecular mass, the number of $\mathrm{mgO}_{2}$ was determined (2):

$$
\mathrm{mgO}_{2}=\mathrm{p} \times \mathrm{V} \times \frac{\% \mathrm{O}_{2}}{\mathrm{R} \times \mathrm{T}} \times 32 \times 1000
$$


The average value of decreasing slope is expressed as function of time and represents the value of specific respirometric activity $\left(\mathrm{mgO}_{2} \cdot \mathrm{h}^{-1}\right)$ which is further divided to the volatile solids present in the system, meaning to the $\mathrm{kg}_{\mathrm{VS}}$ of the sample (3).

$$
\mathrm{RI}=\frac{\mathrm{p} \times \mathrm{V}}{\mathrm{T}} \times 32 \times 1000 \times\left(\frac{\% \mathrm{O}_{21}}{\mathrm{~T}_{1}}-\frac{\% \mathrm{O}_{22}}{\mathrm{~T}_{2}}\right) \times \frac{1}{\mathrm{VS}} \times \frac{1}{\Delta \mathrm{t}}
$$

where $\mathrm{p}$-pressure [atm] equal to the atmospheric pressure; $\mathrm{V}$-free volume expressed in liters; 32 is the molecular mass of oxygen $\left[\mathrm{g} \cdot \mathrm{mol}^{-1}\right]$; vs—is the volatile solids content $[\mathrm{kg}] ; \Delta \mathrm{t}$ - time $[\mathrm{h}]$; $\mathrm{R}=0.0821 \mathrm{l} \cdot \mathrm{atm} \cdot \mathrm{mole}^{-1} \cdot{ }^{\circ} \mathrm{K}^{-1}$ —gas constant; 1 and 2 indicate the points where the calculus was performed.

Equation (3) calculates the specific $\mathrm{RI}\left(\mathrm{mgO}_{2} \cdot \mathrm{kg}_{\mathrm{VS}}{ }^{-1} \cdot \mathrm{h}^{-1}\right)$. The processing of data acquisition during the respirometric experiments was done with the InNet software version (Unievrsity of Trento, Trento, Italy, 2002) [20].

Three types of results are obtained after performing the respirometric experiments:

- $\quad$ RI-respirometric index variation in time (hourly) for each type of material;

- $\mathrm{RI}_{24}$-average of instant values of RI, obtained in the most intense $24 \mathrm{~h}$ of biological activity;

- $\mathrm{RI}_{\max }$-the maximum values registered during the tests.

\subsection{Biogas Methodology}

The test estimating the partial biogas produced lasts 21 days, while estimating the total biogas generation could last up to 100 days [9,18]. One type of analysis proposed in the literature [19] estimates the biogas potential of a substrate based on its respirometric index. This calculation would shorten significantly the time necessary for the biogas potential test and would decrease the operation costs of an anaerobic digestion plant for 100 days.

The equation that determined the anaerobic biogas potential derived from the value of dynamic respirometric index is [19]:

$$
\mathrm{ABP}=(34.4 \pm 2.5)+(0.109 \pm 0.003) \mathrm{DRI}
$$

The ABP and DRI are expressed as Nl. $\mathrm{kg}_{\mathrm{DM}}{ }^{-1}$ and $\mathrm{mgO}_{2} \cdot \mathrm{kg}_{\mathrm{DM}}{ }^{-1} \cdot \mathrm{h}^{-1}$, respectively. This expression was developed by RICICLA Group Di.Pro.Ve from the University of Milan, by studying 46 samples from MBT full-scale plants.

In general, the dynamic method to which the Italian regulations refer to is the Costech method, developed by Di.Pro.Ve (University of Milan).

Given that Equation (4) uses the DRI $\mathrm{Di}_{\text {DiPro.Ve }}$ and in our case the RI was obtained with the Trento method (with AIR-nl reactor), the University of Trento has made a tranche of experimental tests following both methods in order to find a correlation that makes the two DRI comparison possible. The main difference between the two methods is the temperature control during tests. The method developed by the group RECICLA does not control temperature. The data recorded by the Costech respirometer should be reporting oxygen consumption at the reference temperature of $30{ }^{\circ} \mathrm{C}$, the temperature set in our AIR-nl respirometer. The University of Trento group proposed an expression of correlation valid in the range of 20 to $40^{\circ} \mathrm{C}$ [12]:

$$
\mathrm{DRI}_{30^{\circ} \mathrm{C}}=\mathrm{DRI}_{\mathrm{T}} \vartheta^{\left(30^{\circ} \mathrm{C}-\mathrm{T}\right)}
$$

where $\mathrm{T}$-instantaneous temperature at which the measurement is performed (measured by the probe inside the substrate) and $\vartheta$-reference constant, equal to 1.08 .

From this study [12] another Equation of first approximation without accounting for the role of temperature has been made available, allowing the correlation of the two $\mathrm{DRI}_{24}$ values.

$$
\mathrm{DRI}_{24 \text { Costech }}=0.7086 \mathrm{DRI}_{24 \mathrm{AIR}-\mathrm{nl}}
$$


The value of $\mathrm{DRI}_{24}$ is preferred to the value of DRI, since it was determined as the average integral over a period of $24 \mathrm{~h}$ during the maximum oxygen consumption. $\mathrm{DRI}_{24}$ is less affected by any peak oxygen consumption of limited duration in the respirometric path [20]. As it is less affected by error, the value of $\mathrm{DRI}_{24}$ was used to determine the ABP.

\section{Results}

\subsection{Primary Characterization}

The results of the primary and proximate analysis performed are presented in Table 1.

Table 1. Primary and proximate analysis.

\begin{tabular}{cccc}
\hline Sample & Volatile Solids $^{\mathbf{d b}} \mathbf{( \% )}$ & Moisture (\%) & Gross Heating Value $^{\mathbf{d b}} \mathbf{( k J \cdot \mathbf { k g } ^ { - \mathbf { 1 } } \mathbf { ) }}$ \\
\hline WFGM & 98 & 65 & 20,494 \\
RFGM & 98 & 59 & 20,274 \\
WEGM & 98 & 60 & 21,707 \\
REGM & 98 & 54 & 18,494 \\
AP & 90 & 75 & 16,966 \\
OP & 80 & 68 & 12,425 \\
\hline \multicolumn{3}{c}{}
\end{tabular}

The products have high moisture content, making them suitable for respirometric treatment. As expected, the highest moisture is present in fresh grape marc (compared to exhausted grape marc), in apple scraps and in olive pomace. The energetic content of the analyzed dried discarded biomasses is quite high and their use as potential fuels could be very advantageous for power generation. The highest heating value was achieved by grape marc, which is similar to different types of wood in terms of energy and volatile solids content.

The elemental analysis of the dried selected biomass is presented in Table 2.

Table 2. Elemental analysis of biomass samples.

\begin{tabular}{cccccccc}
\hline Sample & $\mathbf{N ~ ( \% )}$ & $\mathbf{C ~ ( \% )}$ & $\mathbf{H ~ ( \% )}$ & $\mathbf{O ~ ( \% )}$ & $\left.\mathbf{C l} \mathbf{( m g} \cdot \mathbf{k g}^{-\mathbf{1}}\right)$ & $\left.\mathbf{H g} \mathbf{( m g} \cdot \mathbf{k g} \mathbf{1}^{\mathbf{1}}\right)$ & $\mathbf{C} / \mathbf{N}$ \\
\hline WFGM & 2.34 & 48.43 & 6.74 & 40.49 & $<50$ & 0.014 & 20.7 \\
RFGM & 2.29 & 50.23 & 6.24 & 39.24 & $<50$ & $<0.05$ & 21.9 \\
WEGM & 1.71 & 49.99 & 6.48 & 39.82 & $<50$ & 0.001 & 29.23 \\
REGM & 2.36 & 43.83 & 6.41 & 45.40 & $<50$ & 0.002 & 18.57 \\
AP & 0.85 & 42.97 & 7.11 & 39.07 & $<50$ & $<0.0005$ & 50.5 \\
OP & 2.05 & 57.83 & 8.32 & 11.80 & 411 & $<0.05$ & 28.2 \\
\hline
\end{tabular}

The elemental composition of the analyzed samples and of grape marc in particular is similar to wood biomass, specifically to different types of conifers.

For an efficient anaerobic digestion, the feedstock $\mathrm{C} / \mathrm{N}$ ratio is an important parameter. According to some sources [25], the optimum $\mathrm{C} / \mathrm{N}$ ratio varies from 15 to 30, while for other authors [26,27] this range was set from 25 to 30 . All the discarded biomasses fall into the same range for $\mathrm{C} / \mathrm{N}$ ratio, except for the apple pomace which presents lower nitrogen content. As a result, these wastes could be suited for anaerobic treatment and biogas production, when looking only at their $\mathrm{C} / \mathrm{N}$ ratio.

The $\mathrm{Cl}$ and $\mathrm{Hg}$ content are important to establish the bio-waste class as solid recovered fuel (SRF). In the UNI CEN/TS 15359 [28], the SRF is classified in 5 categories according to three specific parameters ( $\mathrm{GHV}, \mathrm{Cl}$ and $\mathrm{Hg}$ ). The first one takes the meaning as economic parameter, the second one as technical parameter and the latter as environmental parameter. The importance of $\mathrm{Cl}$ as a technical parameter is due to its intrinsic properties. Even a small presence in the feedstock leads to problems in plants, especially due to its corrosive behavior. 


\subsection{Biological Stability}

For each type of biomass, three respirometric tests were performed to better emphasize the obtained results, due to the heterogeneity of some of the materials. Because the RI testing methodology does not allow for each test choosing a pre-fixed sampling rate at constant moments in time, the statistical analysis was performed only after setting a common $\mathrm{x}$-value for the three replicates. The data from each Test 1-3 was interpolated to determine a new common time value and the average RI variation with standard deviation bars is presented below for each type of material analyzed.

The results for the $\mathrm{RI}$ and $\mathrm{RI}_{24}$ variation are presented in Figures 2-7.

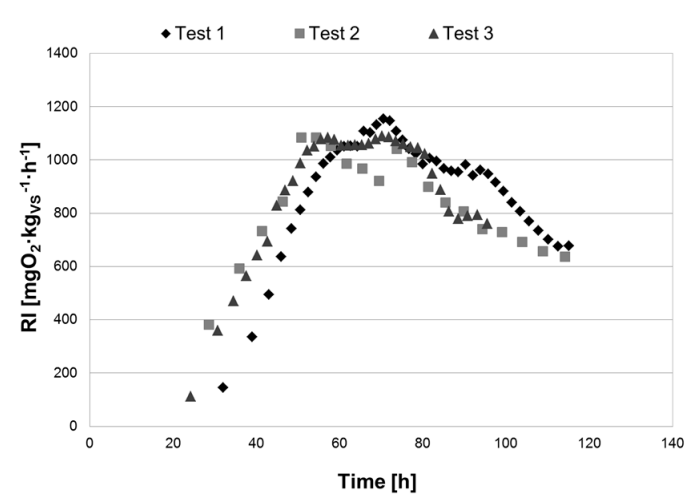

(a)

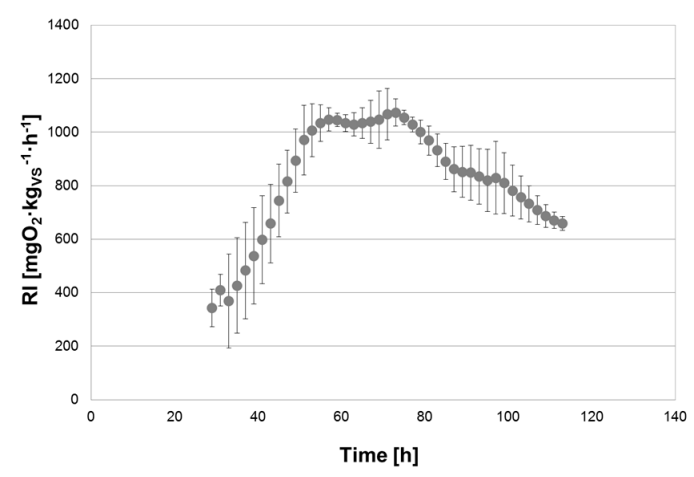

(c)

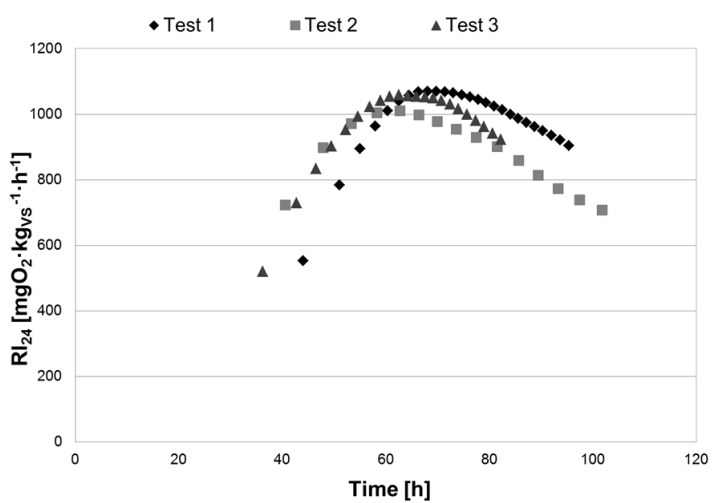

(b)

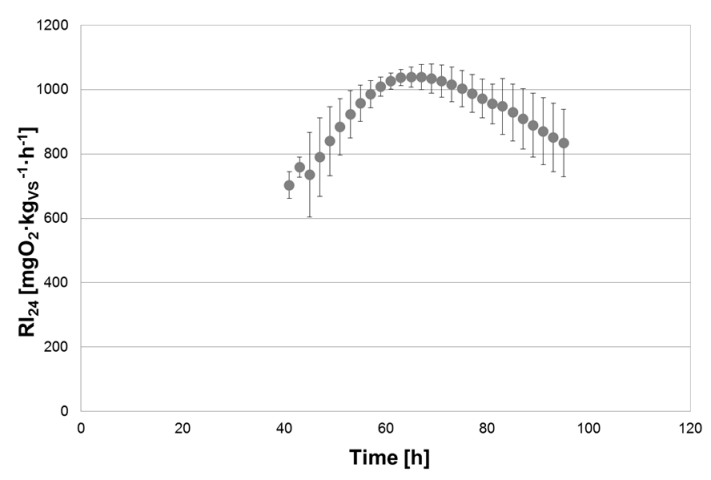

(d)

Figure 2. WFGM respirometric variation: (a) WFGM RI 3 Tests variation; (b) WFGM RI 34 Tests variation; (c) WFGM RI variation; (d) WFGM $\mathrm{RI}_{24}$ variation.

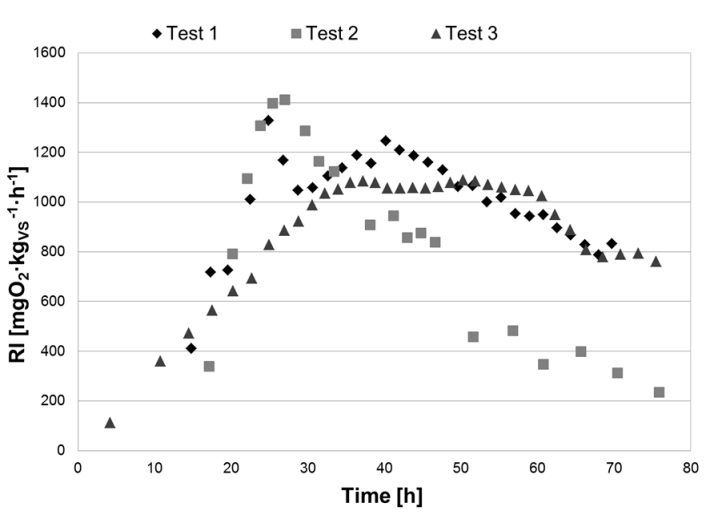

(a)

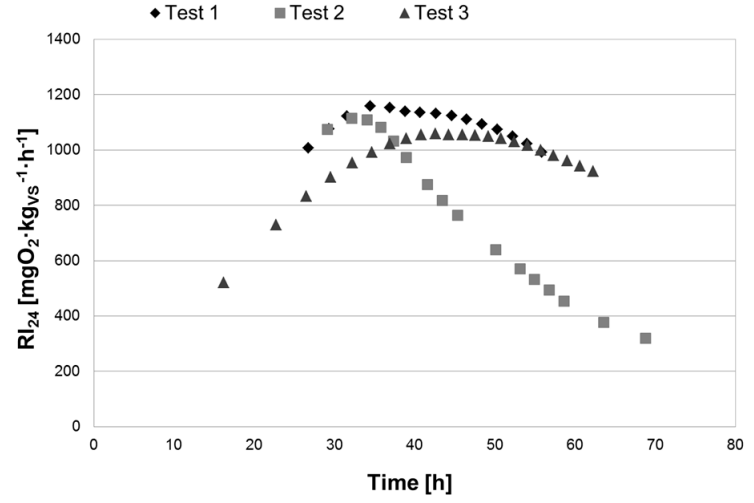

(b)

Figure 3. Cont. 


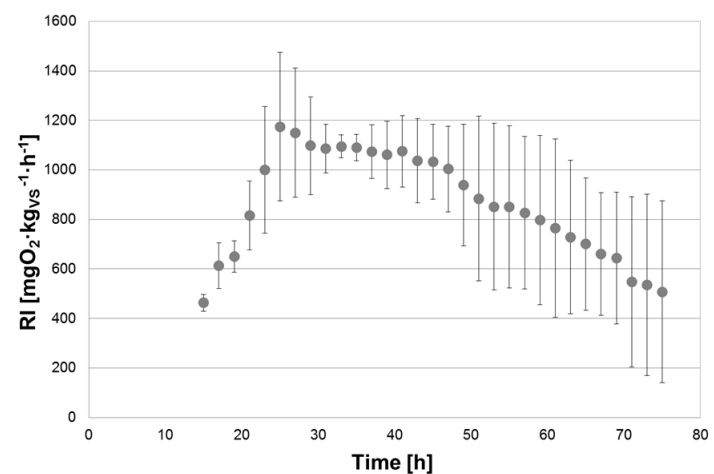

(c)

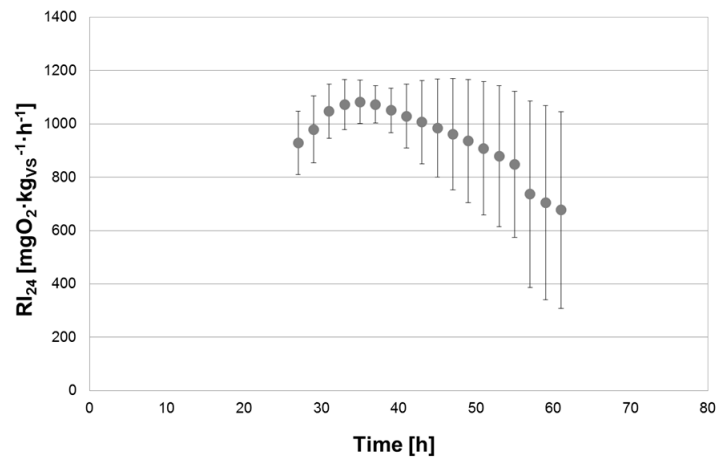

(d)

Figure 3. RFGM respirometric variation: (a) RFGM RI 3 Tests variation; (b) RFGM RI 24 Tests variation; (c) RFGM RI variation; (d) RFGM RI 24 variation.

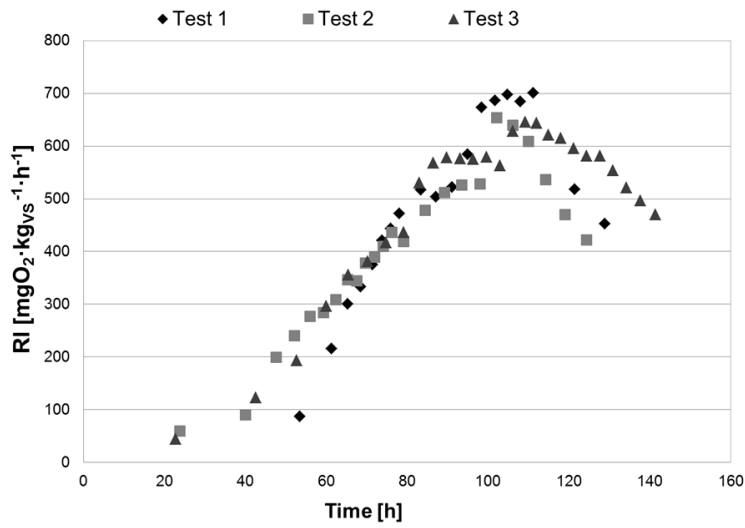

(a)

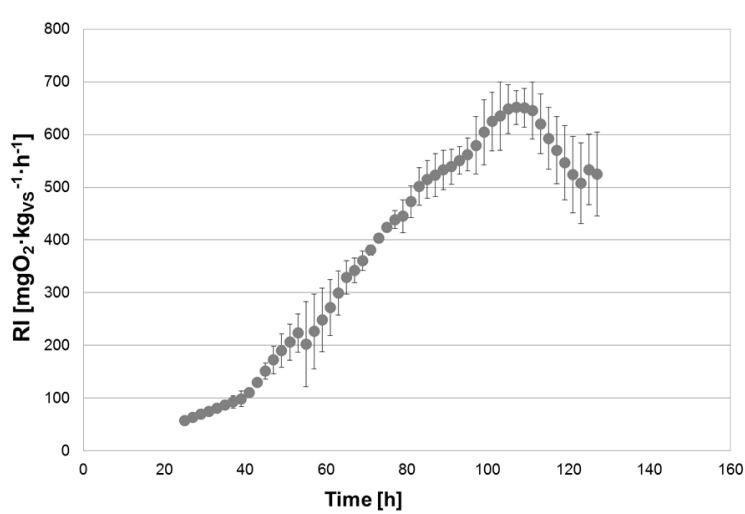

(c)

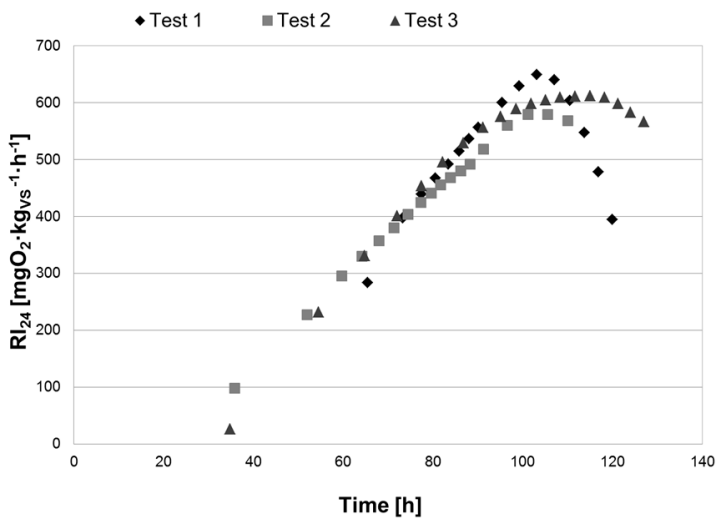

(b)

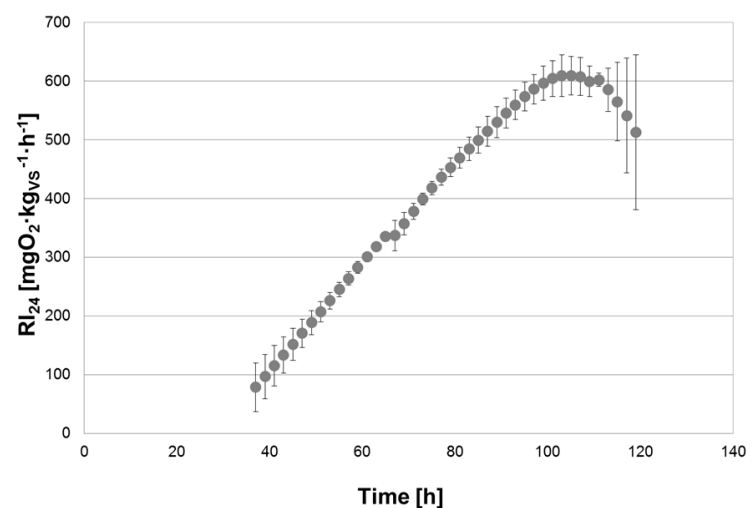

(d)

Figure 4. WEGM respirometric variation: (a) WEGM RI 3 Tests variation; (b) WEGM RI 3 Tests variation; (c) WEGM RI variation; (d) WEGM $\mathrm{RI}_{24}$ variation. 


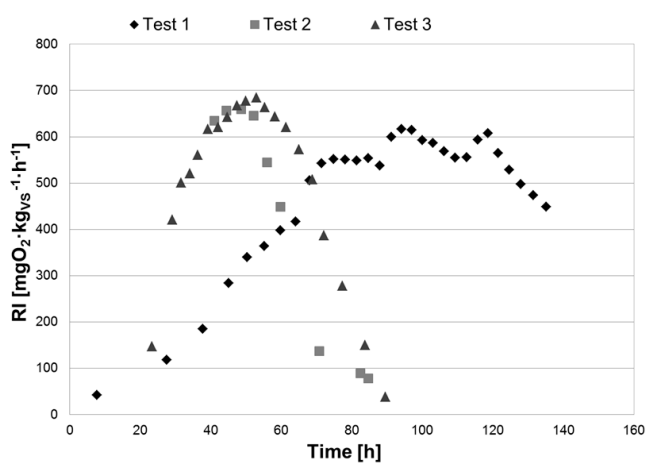

(a)

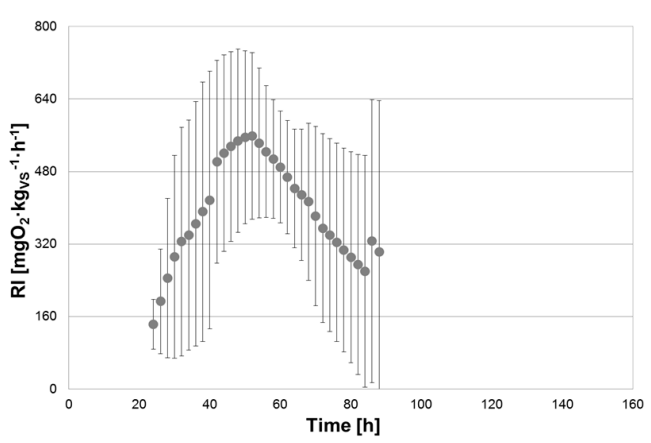

(c)

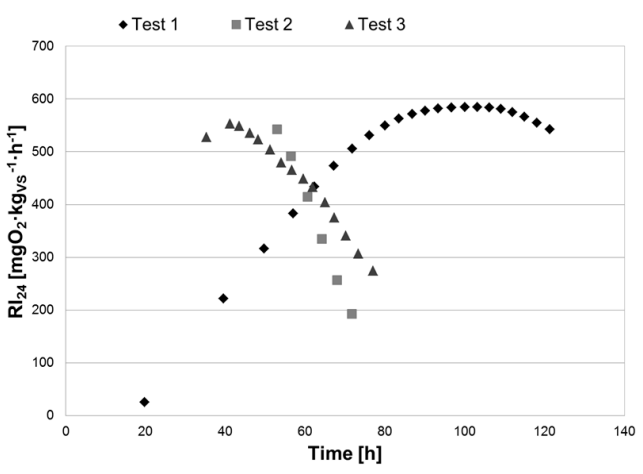

(b)

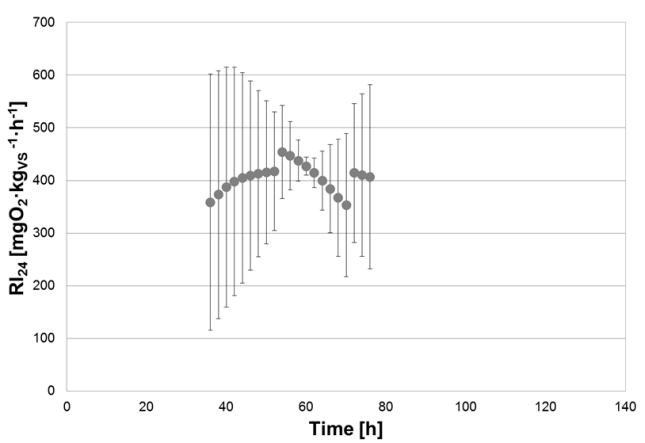

(d)

Figure 5. REGM respirometric variation: (a) REGM RI 3 Tests variation; (b) REGM RI 243 Tests variation; (c) REGM RI variation; (d) REGM $\mathrm{RI}_{24}$ variation.

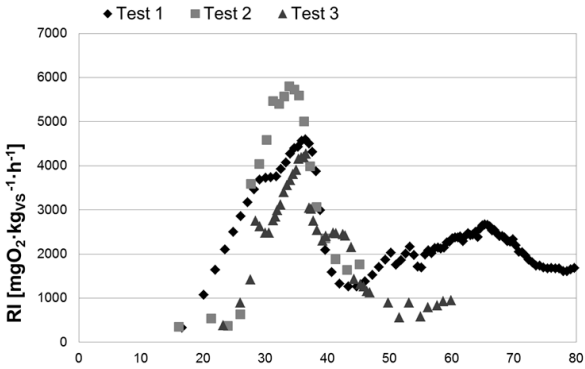

Time [h]

(a)

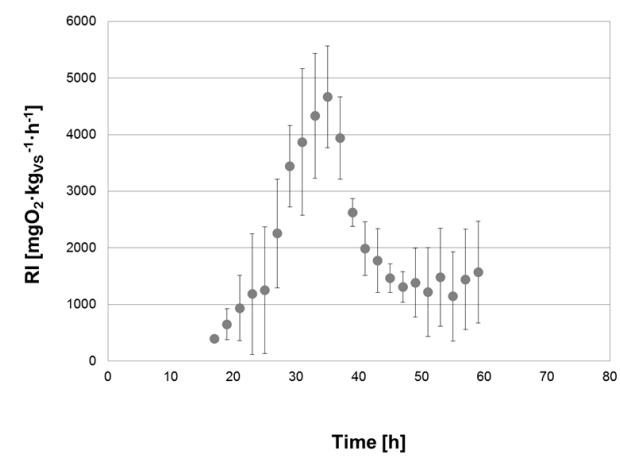

(c)

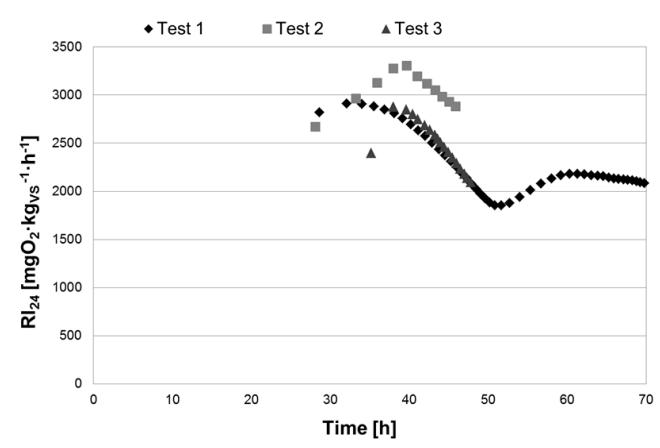

(b)

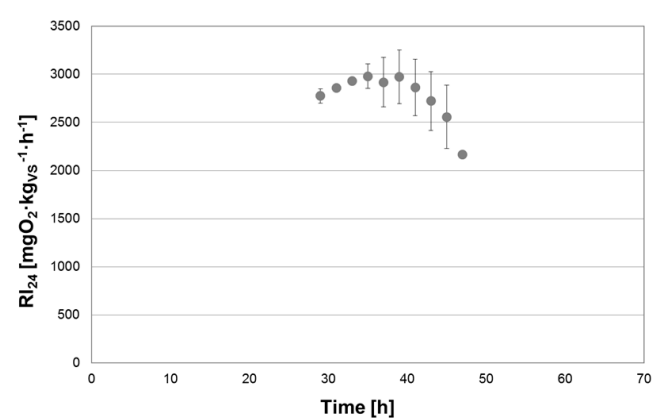

(d)

Figure 6. AP respirometric variation: (a) AP RI 3 Tests variation; (b) AP RI 243 Tests variation; (c) AP $\mathrm{RI}$ variation; (d) $\mathrm{AP} \mathrm{RI}_{24}$ variation. 


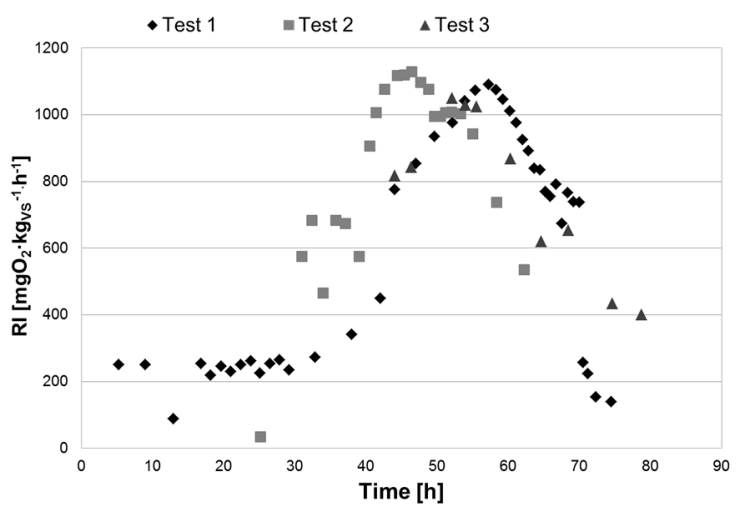

(a)

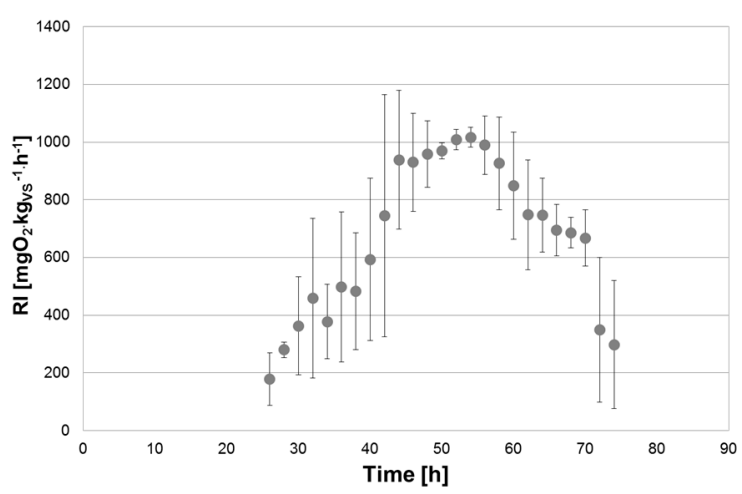

(c)

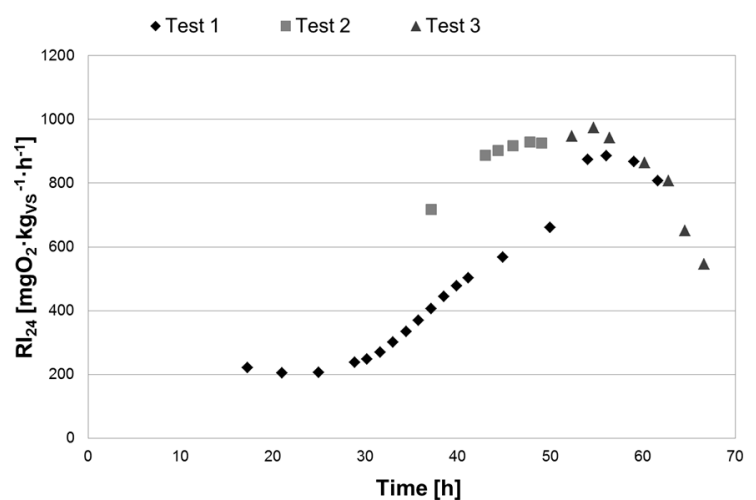

(b)

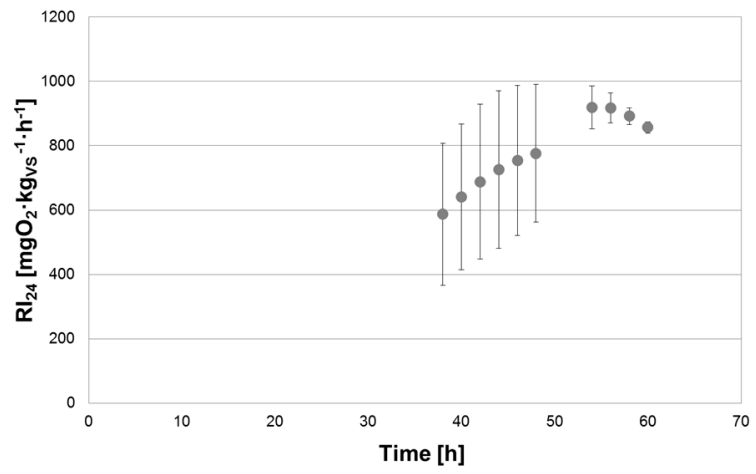

(d)

Figure 7. OP respirometric variation: (a) OP RI 3 Tests variation; (b) OP RI 243 Tests variation; (c) OP RI variation; (d) OP $\mathrm{RI}_{24}$ variation.

The aerobic process occurring during the respirometric index determination has different time lengths for the six types of materials. As expected, differences appeared between the WGM and RGM, due to the different technologies of producing white and red wine [29]. If average length of a test for WFGM was 4-5 days, in the case of RFGM the average was 3 days. For the exhausted grape marc the necessary amount of time for a process run was comparatively higher than all the other types of biomass; as a result, the biological activity of WEGM was measured over 5-6 days, and during 4-5 days for REGM. This shows that the wastes coming from distillation process require a longer period of time for aerobic degradation, leading to higher energy consumption by the biomass aeration equipment.

Interestingly, the difference in white and red grape processing is noticed in the start of the respirometric activity as well. Though the biological activity of RFGM and REGM is measured by the respirometric tests from the first hours of the process, the WFGM and WEGM do not show any periods of activity in the first $20 \mathrm{~h}$. The fact that the white grape marc reacts more slowly to aerobic processing is also observed in the maximum RI values achieved, which are offset by approximately 40-60 h compared to the red grape marc RI maximum.

Shorter periods of time for process run were registered for OP and AP. The duration for OP tests did not exceed 3 days, while for the AP the treatment period was measured for approximately 2 days. These results are possibly connected to the discarded biomasses moisture contents. Higher moisture content favors the biological activity and shortens the length of the process, but a deeper analysis on the porosity role could help.

The differences which appear between tests performed on the same type of material, especially grape marc, are due to the heterogeneous character of the materials. The grape marc consists of seeds, skins, stalks and pulp in different proportions [30]. The tests which have distinct lengths of time for 
the same material can be explained by the load into the reactor of material containing more or less biodegradable matter. Therefore for establishing the RI value for each type of discarded biomass, an average of the three tests and the maximum values encountered are presented in Table 3.

Table 3. Maximum values of $\mathrm{RI}$ and $\mathrm{RI}_{24}$ for the six biomass samples.

\begin{tabular}{|c|c|c|}
\hline Sample & RI Max $\left(\mathrm{mgO}_{2} \cdot \mathrm{kg}_{\mathrm{VS}}{ }^{-1} \cdot \mathrm{h}^{-1}\right)$ & $\mathrm{RI}_{24} \operatorname{Max}\left(\mathrm{mgO}_{2} \cdot \mathrm{kg}_{\mathrm{Vs}}{ }^{-1} \cdot \mathrm{h}^{-1}\right)$ \\
\hline WFGM & $1109 \pm 40$ & $1046 \pm 32$ \\
\hline RFGM & $1276 \pm 167$ & $1110 \pm 50$ \\
\hline WEGM & $665 \pm 29$ & $613 \pm 35$ \\
\hline REGM & $652 \pm 34$ & $560 \pm 22$ \\
\hline AP & $4888 \pm 804$ & $3031 \pm 236$ \\
\hline OP & $1089 \pm 40$ & $929 \pm 44$ \\
\hline
\end{tabular}

The highest registered values were encountered for apple pomace, which has by far the greatest biological activity. The lowest values were recorded for the exhausted grape marc, obtained from the distillation process. These values are comparable to the ones found in the literature for aerobic processes applied to organic fractions, in similar operating conditions [31,32]. According to classifications found in other research studies [16] values of dynamic RI above $3000 \mathrm{mgO} \cdot \mathrm{kg}_{\mathrm{vs}}{ }^{-1} \cdot \mathrm{h}^{-1}$ are considered to be fresh material and belong to class I of stability; values over $2000 \mathrm{mgO}_{2} \cdot \mathrm{kg} \mathrm{VS}^{-1} \cdot \mathrm{h}^{-1}$ belong to class II, while between $1000-2000 \mathrm{mgO}_{2} \cdot \mathrm{kgVs}^{-1} \cdot \mathrm{h}^{-1}$ materials are considered to be in the course of biological decomposition and belong to class III. For class IV, $500-1000 \mathrm{mgO} \cdot \mathrm{Kg}_{\mathrm{Vs}}{ }^{-1} \cdot \mathrm{h}^{-1}$ the materials are moderately stable, while for values below $500 \mathrm{mgO} \cdot \mathrm{kgVs}^{-1} \cdot \mathrm{h}^{-1}$, which represent class $\mathrm{V}$, the substrate is considered biologically stable.

The only material belonging to class I of stability (the least stable) is the apple pomace, which had the highest RI value of $4853 \mathrm{mgO}_{2} \cdot \mathrm{kg} \mathrm{vs}^{-1} \cdot \mathrm{h}^{-1}$. The majority of the discarded biomasses are in the third category, as materials in the course of degradation. Therefore, WFGM, RFGM and OP need a pre-treatment method for biological stabilization before agricultural use. The white and red exhausted grape marc is less biodegradable (belonging to class IV), but cannot be considered stable and stored or used as fertilizer (compost) as it is. According to literature sources, the value of $593 \pm 341 \mathrm{mgO}_{2} \cdot \mathrm{kgVs}^{-1} \cdot \mathrm{h}^{-1}$ corresponds to bio-stabilized wastes [33].

\subsection{Biogas Potential Estimation}

The results for $\mathrm{ABP}$, derived from the values of $\mathrm{RI}_{24}$ using Equations (4)-(6) are presented in Table 4.

Table 4. ABP values for analyzed samples.

\begin{tabular}{|c|c|c|c|c|}
\hline Samples & $\operatorname{ABPmax}\left(\mathrm{Nm}^{3} \cdot \mathrm{t}_{\mathrm{Vs}}{ }^{-1}\right)$ & $\operatorname{ABPmin}\left(\mathrm{Nm}^{3} \cdot \mathrm{t}_{\mathrm{Vs}}{ }^{-1}\right)$ & $\operatorname{ABPmax}\left(\mathrm{Nm}^{3} \cdot \mathrm{t}_{\mathrm{t.q}}{ }^{-1}\right)$ & $\operatorname{ABPmin}\left(\mathrm{Nm}^{3} \cdot \mathrm{t}_{\mathrm{t} \cdot \mathrm{q}}{ }^{-1}\right)$ \\
\hline RFGM & 125.81 & 115.98 & 51.36 & 47.35 \\
\hline REGM & 80.56 & 73.16 & 35.90 & 32.60 \\
\hline WEGM & 86.35 & 78.64 & 33.64 & 30.64 \\
\hline WFGM & 120.72 & 111.17 & 41.02 & 37.77 \\
\hline $\mathrm{AP}$ & 281.58 & 263.13 & 65.10 & 60.84 \\
\hline OP & 119.86 & 109.66 & 30.9 & 27.99 \\
\hline
\end{tabular}

The results of $\mathrm{ABP}$ were calculated at standard conditions $\left(\mathrm{p}=1 \mathrm{~atm}\right.$ and $\left.\mathrm{T}=0{ }^{\circ} \mathrm{C}\right)$ and expressed as the $\mathrm{m}^{3}$ of biogas ton produced per ton of feedstock VS, as typically done in the literature [34].

The results obtained are comparable with other studies from the literature [35-41]. For example Battista et al. [35] determined experimentally $5.40-14.10 \mathrm{~m}^{3} \cdot \mathrm{t}^{-1}$ biogas produced from different samples of olive pomace. In another study [36], the authors performed the ABP test on Italian white and red grape marc and obtained values of $245.32 \mathrm{~m}^{3} \cdot \mathrm{t}_{\mathrm{VS}}{ }^{-1}$ and $144.97 \mathrm{~m}^{3} \cdot \mathrm{t}_{\mathrm{VS}}{ }^{-1}$, respectively. The white grape marc ABP values calculated in this paper are significantly lower, however the same authors [36] show 
$\mathrm{ABP}$ values for white grape marc skins of $142.37 \mathrm{~m}^{3} \cdot \mathrm{tvs}_{\mathrm{Vs}}^{-1}$ and $128.34 \mathrm{~m}^{3} \cdot \mathrm{t}_{\mathrm{Vs}}{ }^{-1}$ for white grape marc stalks. Dinuccio et al. [37] found the specific biogas yield of grape marc to be $139 \mathrm{~m}^{3} \cdot \mathrm{t}^{-1}$ and $64 \mathrm{~m}^{3} \cdot \mathrm{t}^{-1}$ for grape stalks. This confirms that the heterogeneity and specific characteristics of the material play an important role in the repeatability of the ABP tests. When handling heterogeneous materials such as the ones studied in this paper, the success of running a continuous process depends on the reliability and swiftness of the feedstock characterization methods.

It should be noted that not all the biomass studied has a good ABP, in particular the exhausted grape marc with values below $100 \mathrm{~m}^{3} \cdot \mathrm{tvs}_{\mathrm{Vs}}{ }^{-1}$. For WEGM and REGM other types of energy recovery processes could be applied. It could be possible to send these biomasses to a drying and pelletizing facility and then to thermal treatment for power generation. Moreover, the proposed approach allows for optimizing co-treatment strategies with source-separated food waste from MSW, specifically in the case of anaerobic digestion followed by post-composting; indeed, as a result of RI, the data generation and the calculation of ABP, it is possible to decide in which step of treatment a biomass should be added to be co-treated: in the case of low ABP it should be sent directly to the post-composting stage, while in the case of high ABP, additional information (e.g., lignin content, $\mathrm{C} / \mathrm{N}$ ratio) could be added to be sure about the compatibility in co-digestion.

\section{Conclusions}

This study emphasized the significant information which can be obtained by using respirometric index methods and proves that the correlation of ABP and RI is a useful method to determine in a shorter amount of time the value of biogas production potential. This method would improve the processing time from 21-60 days to just 1-4 days to conduct a respirometric test. Therefore, plant operators could use this method to optimize the feedstock for biogas generation.

Author Contributions: Elena Cristina Rada, Marco Ragazzi, Cristina Rada and Stefano Antognoni conceived and designed the experiments; Simona Ciuta and Stefano Antognoni performed the experiments; Simona Ciuta, Stefano Antognoni, Elena Cristina Rada and Marco Ragazzi analyzed the data; Adrian Badea and Lucian Ionel Cioca contributed materials/analysis tools; all authors wrote the paper.

Conflicts of Interest: The authors declare no conflict of interest.

\section{References}

1. European Comission. Directive 1999/31/EEC on the Landfill of Waste. 1999. Available online: http:/ / eur-lex.europa.eu/legal-content/en/TXT/?uri=CELEX\%3A31999L0031 (accessed on 13 December 2016).

2. Cardoen, D.; Joshi, P.; Sarma, M.P.; Pant, D. Agriculture biomass in India: Part 2. Post-harvest losses, cost and environmental impacts. Resour. Conserv. Recycl. 2015, 101, 143-153. [CrossRef]

3. Vitali, F.; Parmigiani, S.; Vaccari, M.; Collivignarelli, C. Agricultural waste as household fuel: Techno-economic assessment of a new rice-husk cookstove for developing countries. Waste Manag. 2013, 33, 2762-2770. [CrossRef] [PubMed]

4. Ionescu, G.; Marculescu, C.; Badea, A. Alternative solutions for MSW to energy conversion. UPB Sci. Bull. 2011, 73, 243-254.

5. Rada, E.C. Energy from municipal solid waste. WIT Trans. Ecol. Environ. 2014, 190, 945-958.

6. Raviv, M. Can the use of composts and other organic amendments in horticulture help to mitigate climate change? Acta Hortic. 2015, 1076, 19-28. [CrossRef]

7. Pognani, M.; Barrena, R.; Font, X.; Adani, F.; Scaglia, B.; Sanchez, A. Evolution of organic matter in a full-scale composting plant for the treatment of sewage sludge and biowaste by respiration techniques and pyrolysis-GC/MS. Bioresour. Technol. 2011, 102, 4536-4543. [CrossRef] [PubMed]

8. Scaglia, B.; Adani, F. An index for quantifying the aerobic reactivity of municipal solid wastes and derived waste products. Sci. Total Environ. 2008, 394, 183-191. [CrossRef] [PubMed]

9. Antognoni, S.; Ragazzi, M.; Ionescu, G.; Passamani, G.; Zanoni, S.; Rada, E.C.; Torretta, V. Respirometric index as a tool for biogas generation production from poultry manure. Manag. Environ. Qual. 2016, 27, $269-280$. [CrossRef] 
10. Adani, F.; Ubbiali, C.; Generini, P. The determination of biological stability of composts using the Dynamic Respiration Index: The results of experience after two years. Waste Manag. 2006, 26, 41-48. [CrossRef] [PubMed]

11. Spanjers, H.; Vanrolleghem, P.; Olsson, G.; Dold, P. Respirometry in control of the activated sludge process. Water Sci. Technol. 1996, 34, 117-126. [CrossRef]

12. Rada, E.C.; Ragazzi, M.; Venturi, V. Critical analysis of two respirometric methods for solid substrates based on continuous and semi-continuous aeration. J. Bioremed. Biodegrad. 2012. [CrossRef]

13. Paletski, W.T.; Young, J.C. Stability measurement of biosolids compost by aerobic respirometry. Compost Sci. Util. 1995, 3, 16-24. [CrossRef]

14. Scaglia, B.; Tambone, F.; Genevini, P.L.; Adani, F. Respiration index determination: Dynamic and static approaches. Compost Sci. Util. 2000, 8, 90-98. [CrossRef]

15. Adani, F.; Lozzi, P.; Genevini, P. Determination of biological stability by oxygen uptake on Municipal Solid Waste and derived products. Compost Sci. Util. 2001, 9, 163-178. [CrossRef]

16. Adani, F.; Tambone, F.; Gotti, A. Biostabilization of municipal solid waste. Waste Manag. 2004, 24, 775-783. [CrossRef] [PubMed]

17. Capodaglio, A.G.; Ranieri, E.; Torretta, V. Process enhancement for maximization of methane production in codigestion biogas plants. Manag. Environ. Qual. 2016, 27, 289-298. [CrossRef]

18. Hansen, T.L.; Schmidt, J.E.; Angelidaki, I.; Marca, E.; Jansen, J.I.; Mosbaek, H.; Christensen, T.H. Method for determination of methane potentials of solid organic waste. Waste Manag. 2004, 24, 393-400. [CrossRef] [PubMed]

19. Scaglia, B.; Confalonieri, R.; D’Imporzano, G.; Adani, F. Estimating biogas production of biologically treated municipal solid waste. Bioresour. Technol. 2010, 101, 945-952. [CrossRef] [PubMed]

20. Dallago, L. Sviluppo e Applicazione di Tecniche Respirometriche per Valutare la Stabilita di Matrici Solide in Fase di Compostaggio. Ph.D. Thesis, University of Trento, Trento, Italy, 2002. Available online: http:/ / www.ing.unitn.it/ dallagol/ (accessed on 13 December 2016). (In Italian)

21. Ciuta, S.; Marculescu, C.; Dinca, C.; Badea, A. Primary characterization of wine making and oil refining industry wastes. UPB Sci. Bull. 2011, 73, 307-320.

22. Rada, E.C.; Ragazzi, M.; Fiori, L.; Antolini, D. Bio-drying of grape marc and other biomass: A comparison. Water Sci. Technol. 2009, 60, 1065-1070. [CrossRef] [PubMed]

23. Ciuta, S.; Rada, E.C.; Ragazzi, M.; Marculescu, C.; Badea, A.; Ionescu, G. Wine making industry wastes biodegradable properties characterization for biogas conversion. In Proceedings of WasteEng ${ }^{12}$ : 4th International Conference on Engineering for Waste and Biomass Valorisation, Porto, Portugal, 10-13 September 2012; pp. 1224-1229.

24. Elmekawy, A.; Diels, L.; Bertin, L.; de Wever, H.; Pant, D. Potential biovalorization techniques for olive mill biorefinery wastewater. Biofuels Bioprod. Biorefin. 2014, 8, 283-293. [CrossRef]

25. Haug, R.T. Biofiltration. In The Practical Handbook of Compost Engineering; CRC Press: Boca Raton, Fl, USA, 1993; pp. 586-600.

26. Huang, G.F.; Wong, J.W.C.; Wu, Q.T.; Nagar, B.B. Effect of $\mathrm{C} / \mathrm{N}$ on composting of pig manure with sawdust. Waste Manag. 2004, 24, 805-813. [CrossRef] [PubMed]

27. Zhu, N. Effect of low initial $\mathrm{C} / \mathrm{N}$ ratio on aerobic composting of swine manure with rice straw. Bioresour. Technol. 2007, 98, 9-13. [CrossRef] [PubMed]

28. Rada, E.C.; Andreottoala, G. RDF/SRF which perspective for its future in EU. Waste Manag. 2012, 32, 1059-1060. [CrossRef] [PubMed]

29. Dabija, A. Tehnologii de Valorificare a Tescovinei. Ph.D. Thesis, University of Stefan cel Mare, Suceava, Romania, March 2009. (In Romanian)

30. Marculescu, C.; Ciuta, S. Wine industry waste thermal processing for derived fuel properties improvement. Renew. Energy 2013, 57, 645-652. [CrossRef]

31. Iglesias Jimenez, E.; Perez Garcia, V. Evaluation of city refuse compost maturity: A review. Biol. Wastes 1989, 27, 115-142. [CrossRef]

32. Barrena, R.; Turet, J.; Busquets, A.; Farres, M.; Font, X.; Sanchez, A. Respirometric screening of several types of manure and mixtures intended for composting. Bioresour. Technol. 2011, 102, 1367-1377. [CrossRef] [PubMed] 
33. Lasaridi, K.E.; Stentiford, E.I. A simple respirometric technique for assessing compost stability. Water Res. 1998, 32, 3717-3723. [CrossRef]

34. Morosini, C.; Conti, F.; Torretta, V.; Rada, E.C.; Passamani, G.; Schiavon, M.; Cioca, L.I.; Ragazzi, M. Biochemical Methane Potential assays to test the biogas production from the anaerobic digestion of sewage sludge and other organic matrices. WIT Trans. Ecol. Environ. 2016, 205, 235-243.

35. Battista, F.; Fino, D.; Erriqueens, F.; Mancini, G.; Ruggeri, B. Scaled-up experimental biogas production from two agro-food waste mixtures having high inhibitory compound concentrations. Renew. Energy 2015, 81, 71-77. [CrossRef]

36. Fabbri, A.; Bonifazi, G.; Serranti, S. Micro-scale energy valorization of grape marcs in winery production plants. Waste Manag. 2015, 36, 156-165. [CrossRef] [PubMed]

37. Dinuccio, E.; Balsari, F.; Gioelli, F.; Menardo, S. Evaluation of biogas productivity potential of some Italian agro-industrial biomasses. Bioresour. Technol. 2010, 101, 3780-3783. [CrossRef] [PubMed]

38. Rugerri, B.; Battista, F.; Bernardi, M.; Fino, D.; Mancini, G. The selection of pretreatment options for anaerobic digestion (AD): A case-study in olive oil waste production. Chem. Eng. J. 2015, 259, 630-639. [CrossRef]

39. Battista, F.; Ruggeri, B.; Fino, D.; Erriquens, F.; Rutigliano, L.; Mescia, D. Toward the scale-up of agro food feed mixture for biogas production. J. Environ. Chem. Eng. 2013, 1, 1223-1230. [CrossRef]

40. Ruffino, B.; Fiore, S.; Roati, C.; Campo, G.; Novarini, D.; Zanetti, M. Scale effect of anaerobic digestion tests in fed-bach and semi-continuous mode for the technical and economic feasibility of a full scale digester. Bioresour. Technol. 2015, 182, 302-313. [CrossRef] [PubMed]

41. Roggio, V.; Comino, E.; Rosso, M. Energy production from anaerobic co-digestion processing of cow slurry, olive pomace and apple pulp. Renew. Energy 2015, 83, 1043-1049. [CrossRef]

(C) 2016 by the authors; licensee MDPI, Basel, Switzerland. This article is an open access article distributed under the terms and conditions of the Creative Commons Attribution (CC-BY) license (http:/ / creativecommons.org/licenses/by/4.0/). 